\title{
KUALITAS PELAYANAN PUBLIK DALAM MEKANISME PELAYANAN KARTU KELUARGA DI KECAMATAN PURWOSARI KABUPATEN PASURUAN
}

\author{
${ }^{1}$ Aminullah ${ }^{2}$ Israyati Rifqoh \\ Jurusan Administrasi Publik, Fakultas IImu Sosial dan Politik, Universitas Yudharta Pasuruan \\ aminullah@yudharta.ac.id, israyatirifaoh@gmail.com \\ PASURUAN JAWA TIMUR - INDONESIA
}

\begin{abstract}
Public service is the State's effort to fulfill the basic needs of every citizen's civil rights for goods, services or services. The purpose of this study is to determine the quality of service for making family cards in Purwosari sub-district. promise and on time, responsive or alertness of officers in helping to serve and handle community complaints in obtaining information. The research method used in this research is qualitative research with descriptive analysis methods with primary data collection techniques carried out by interviewing by asking questions from the community service users in the sub-district purwosari, with the help of data obtained by literature study and field observations.
\end{abstract}

Keywords: Family card; Public service; Quality

\begin{abstract}
Abstrak
Pelayanan publik merupakan upaya Negara untuk memenuhi kebutuhan dari dasar hak sipil setiap warga Negara atas barang jasa maupun pelayanan.Tujuan penelitian ini adalah untuk mnegetahui kualitas pelayanan pembuatan kartu kelurga dikecamatan purwosari, variable yang diteliti dalam penelitian adalah Kualitas Pelayanan dengan indicator seperti pemberian pelayanan sesuai janji dan tepat waktu,responsive atau kesigapan petugas dalam membantu melayani dan menangani keluhan masyarakat dalam memperoleh informasi.Metode penelitian yang digunakan dalam penelitian ini adalan penelitian kualitatif dengan metode deskriptif analisis dengan teknik pengumpulan data primer dilakukan dengan wawancara dengan memberikan pertanyaan masyarakat pengguna jasa pelayanan dikecamatan purwosari,dengan dibantu data yang diperoleh studi pustaka dan observasi lapangan.
\end{abstract}

Kata Kunci: Kartu Keluarga; Kualitas; Pelayanan publik

Open Access at:http://ojs.uho.ac.id/index.php/PUBLICUHO/index

Journal Publicuho is licensed under a Creative Commons Attribution 4.0 International License. 


\section{Journal Publicuho}

ISSN2621-1351 (online), ISSN 2685-0729 (print)

Volume 4 Number 1 (February-April), (2021)pp.78-89

Accredited SINTA SK.NOMOR 28/E/KPT/2019

Open Access at:http://ojs.uho.ac.id/index.php/PUBLICUHO/index

DOI: 10.35817/jpu.v4i1.16233

\section{PENDAHULUAN}

Pelayanan publik (public service) merupakan salah satu perwujudan dari fungsi pada aparatur Negara sebagai abdi masyarakat,pelayanan public dimaksudkan untuk mensejahterakan masyakarat atau warga Negara. Pelayanan public yang professional itu artinya pelayanan public yang bercirikan dengan adanya akuntabilitas dan responsibilitas dari pemberi layanan (aparatur pemerintaha).

Setiap manusia pada dasarnya membutuhkan pelayanan,bisa dikatakan bahwa pelayanan tidak dapat dipisahkan dengan kehidupan manusia.Masyarakat setiap waktunya selalu menuntut pelayanan yang berkualitas dari pemerinta,meskipun tuntutan itu tidak sesuai dengan harapan.

Undang-undang nomor 25 tahun 2009 menyatakan bahwa pelayanan publik merupakan kegiatan atau rangkaian kegiatan dalam rangka pemenuhan kebutuhankebutuhan pelayanan sesuai dengan peraturan perundang-undangan bagi setiap warga Negara dan penduduk atas barang,jasa maupun pelayanan administrasi yang disediakan oleh penyelenggara pelayanan.

Dengan diterbitkan Undang-undang Nomor 23 tahun 2006 tentang administrasi kependudukan untuk memeberikan perlindungan, pengakuan, penentuan status pribadi dan status hukum setiap peristiwa penting yang dialami oleh penduduk Indonesia maupun warga Negara Indonesia yang berada diluar wilayah Negara kesatuan Republik Indonesia yang berada pengaturan administrasi kepedudukan.

Adminitrasi kependudukan adalah rangkaian kegiatan penataan dan penerbitan dokumen dan data kependudukan melalui pendaftaran penduduk ,pencatatan sipil, pengelolaan informasi administrasi kependudukan yang hasilnya untuk pelayanan public dan pembagunan.pelayanan public merupakan suatu hal yang sangat mendasar bagii instasi pemerintah maupun swasta. Menurut Sinambela (2006), pemahamam tetang ciri-ciri pelayanan public yang baik dan berkualitas sangat bermanfaat bagi aparat pemerintahan untuk mempersiapkan segala sesuatunya termasuk dalam hal sarana pelayanan dan strategi yang akan diterapkan .

Kedisipilinan dalam memberikan pelayanan publik merupakan keharusan, mengingat adanya kecenderungan aparat pemerintah sebagai manusia yang didak luput dari kesalahan maupun kekeliruan. Pelayanan public merupakan tugas utama aparat selain untuk membangun kepercayaan masyarakat terhadap pemerintah. Dengan demikian ,aparat sebagai pelayan masyarakat diharapkan dapat menjalalankan tuganya dengan baik, tepat dan cepat serta menjamin terpeliharanya tata tertib dan kelancaran 
pelaksaan tugas. Hal itu ditegaskan dalam Undang -undang Nomor 43 Tahun 1999 tentang pokok -pokok kepegawaian, bahwa kedudukan aparatur Negara itu sangat penting sebagai abdi Negara dan abdi masyarakat peranan dan kedudukanya sangat penting dan diharapkan agar setiap aparat dapat memuaskan perhatian maupun pikiran serta mengarahkan segala daya dan tenaganya untuk menyelenggarakan pelayanan yang efesien dan efektifitas.

Dalam Peraturan Bupati Pasuruan Nomor 5 Tahun 2017 tentang penyelenggaraan pelayanan perizinan terpadu satu pintu bahwa dalam rangka mewujudkan pelayanan public yang cepat, murah, mudah, transparan, pasti dan terjangkau makan perlu menyerderhanakan prosedur dan memudahkan permohonan izin dalam memperoleh perizinan.dimana kenyataannya pembuatan Kartu Kelvarga (KK), dinilai oleh masyarakat sangat rumit,panjang dan terlalu berbelit-belit dalam proses pengisian formulir yang menjadi syarat untuk mendapatkan Kartu Kelurga (KK) dan apabila ada yang dirubah di dalam kartu Kelvarga maka harus melengkapi syarat tambahan misalnya dalam perubahan tangga lahir,tempat lahir, atau merubah status dari belum kawin menjadi kawin harus dilengkapi dengan buku nikah.

Kartu Kelurga,Selanjutnya disingkat (KK) adalah kartu identitas keluarga yang memuat data tentang nama,susunan dan hubungan dalam keluarga serta identitas anggota kelurga. Penduduk warga Negara Indonesia wajib melaporkan susunan keluarganya kepada instansi pelaksana melalui Kepala desa atau Lurah dan camat. Adapun persyaratan penerbitan kartu keluarga yaitu :

- Mengisi Formulir biodata

- Pengantar Rt/Rw

- Foto copy Akte perkawinan / buku nikah yang sudah di legaliser

- Foto Copy Akte Kematian

- Foto Copy Akte Perceraian

- Foto Copy Keterangan Kelahiran

- Foto Copy ljazah sebagai data pendukung bila ada

- Foto Copy KTP suami dan istri

- Kartu kelurga lama yang asli

- Surat keterangan kehilangan KTP/KK dari kepolisian

- Surat pindah penduduk yang pindah dalam wilayah RI

- Tanda tangan Lurah dan Camat Atau yang mewakili

Masyarakat yang belum begitu paham tentang alur dan prosedur pelayanan sangat membutuhkan bantuan dari petugas pelayanan untuk dapat menjelaskannya. 


\section{Journal Publicuho}

ISSN2621-1351 (online), ISSN 2685-0729 (print)

Volume 4 Number 1 (February-April), (2021)pp.78-89

Accredited SINTA SK.NOMOR 28/E/KPT/2019

Open Access at:http://ojs.uho.ac.id/index.php/PUBLICUHO/index

DOI: 10.35817/jpu.v4i1.16233

\section{METODOLOGI}

Metode yang digunakan dalam penelitian ini adalah metode kualitatif .Menurut Bogdan dan Taylor (Moleong 2006;4),kualitatif sebagai prosedur penelitian yang menghasilkan data deskriptif berupa kata-kata tertulis atau lisan dari orang-orang dan perilaku yang dapat diamati,pendekatan ini diarahkan latar dan individu secara utuh . demikian menurut Nawawi $(2007 ; 67)$ metode desktiptif dapat diartikan sebagai prosedur pemecahan masalah yang diselidikicdengan menggambarkan atau melukiskan keadaan subyek atau objek penelitian (seseorang lembaga,masyarakat dan lain-lain) pada saat ini berdasarkan fakta-fakta yang tampak atau sebagimana adanya.

Sesuai dengan jenis permasalahan yang diteliti maka metode penelitian lapangan yang digunakan adalah metode kualitatif yang berlokasi di Kecamatan Purwosari Kabupaten Pasuruan .Berkaitan dengan jenis penelitian yang digunakan, maka data yang digunakan dalam penelitian ini meliputi data primer yakni data yang diperoleh melalui penelitian langsung dilapangan.

Menggunakan sumber data primer dan sukender,sumber data primer dalam penelitian ini adalah kualitas pelayanan dalam perbaikan atau perggantian Kartu Kelurga (KK) dikecamatan Purwosari Kabupaten Pasuruan.Data skunder dari penelitian ini bersumber dari buku ,catatan,jurnal,maupun arsip yang ada dipelayanan dalam perbaikan maupun perggantian Kartu Keluarga (KK) di Kecamatan Purwosari Kabupaten Pasuruan.

Peneliti dalan penelitian ini menggunakan teknik pengumpulan data seperti wawancara,observasi dan dokumentasi.Dalam penelitian ini,analisis data yang digunakan menggunakan analisis data model Miles dan Huberman yang terdiri daei pengumpulan data (data colletion),reduksi data (data reduction), penyajian data (data diplay) dan penarikan kesimpulan verifikasi (conclusion and verificatio).

\section{HASIL DAN PEMBAHASAN}

Pelayanan publik dalam mekanisme perbaikan atau pergantian kartu keluarga (KK) di Kecamatan Purwosari dilaksanakan oeleh Seksi Pemeritahan yang mempunyai tugas pokok membatu Camat dalam menyiapkan bahan rumusan kebijakan dan pelaksanaan peyelenggraan pemerintahan yang meliputi : otonomi daerah, politik dalam negeri, dan administrasi publik, kependudukan, hokum perundang-undagan, perimbangan keuangan daerah, dan fasilitasi penyelenggraan pemerintahan desa/kelurahan, serta melaksanakan tugas-tugas lain sesuai dengan katentuan yang berlaku. Diantara fungsi-fungsi tersebut dijelaskan bahwa fungsi dari Seksi Pemerintah yaitu menyusun rencana program dan kegiatan pelayanan penyelenggaraan pemerintah Kecamatan dan melaksanakan pelayanan penyelenggraan pemerintahan kecamatan. Dan diantara mengenai pelayanan kartu kelurga (KK) .Di kecamatan Purwosari itu sendiri peleyanan KK diatur oleh Standart 
Operasional Prosedur (SOP) yang bertujuan agar pegawai memahami tahapan- tahapan yang harus dilakukan dalam proses perbaikan atau pergantian KK. Dan pegawai Kecamatan wajib mengikuti tahapan-tahapan yang sesuai dengan SOP yang sudah ditetapkan tersebut.

Pendudukk warga Negara Indinesia dan orang asingyang memiliki izin tinggal tetap wajib melaporkan susunan kelurganya kepada Dinas Kependudukan dan Pencatatan sipil melalui kepala desa/lurah dan camat. Pelaporan tersebut sebagai dasar untuk penerbitan, perbaikan atau pergantian Kartu Keluarga . berikut ini dalah syarat-syarat penerbitan, perbaikan dan pergantian Kartu Kelurga, yaitu :

a. Penerbitan Kartu Keluarga baru bagi penduduk WNI DAN WNA yang memiliki Izin Tinggal Tetap dilakukan setelah memenuhi syarat berupa :

1) Surat pengatar RT/RW

2) Izin Tinggal Tetap bagi orang asing

3) Foto Copy /menunjukkan Akta Nikah/Kutipan Akta Perkawinan

4) Surat keterangan Pindah / Surat keterangan Pindah Datang bagi penduduk yang pindah dalam wilayah Negara Kesatuan Republik Indonesia.

5) Surat keterangan Datang dari Luar Negeri yang diterbitkan oleh Dinas Kependudukan dan Pencatatan Sipil bagi warga Negara Indonesia yang datang dari Luar Negeri karena pindah.

b. Perbaikan atau perubahan Kartu Kelvarga karena penambahan anggota keluarga dalam Kartu Keluarga bagi penduduk yang mengalami kelahiran dilakukan memenuhi syarat berupa :

1) KK lama

2) Kutipan Akta Kelahiran.

c. Perubahan Kartu Kelurga karena penambahan enggota keluarga untuk menumpang ke dalam Kartu Keluarga bagi penduduk Warga Negara Indonesia dilakukan setelah memenuhi Syarat berupa :

1) KK lama

2) KK yang akan ditumpangi

3) Surat Keterangan Pindah Datang bagi penduduk yang pindah dalam wilayah Negara Kesatuan Republik Indonesia; dan/atau

4) Surat Keterangan Datang dari Luar Negeri bagi Warga Negara Indonesia yang datang dari Luar Negeri karena pindah

d. Perubahan Kartu Keluarga karena penambahan anggota keluarga bagi Orang Asing yang memiliki Izin Tinggal Tetap untuk menumpang ke dalam Kartu Keluarga bagi penduduk Warga Negara Indonesia atau Orang Asing dilakukan setelah memenuhi syarat berupa 


\section{Journal Publicuho}

ISSN2621-1351 (online), ISSN 2685-0729 (print)

Volume 4 Number 1 (February-April), (2021)pp.78-89

Accredited SINTA SK.NOMOR 28/E/KPT/2019

Open Access at:http://ojs.uho.ac.id/index.php/PUBLICUHO/index

DOI: 10.35817/jpu.v4i1.16233

1) KK lama atau KK yang ditumpangi

2) Paspor

3) Izin Tinggal Tetap dan

4) Surat Keterangan Catatan Kepolisian bagi orang asing Tinggal Tetap

e. Perubahan Kartu Keluarga karena penggurangan anggota keluarga dalam Kartu Kelvarga bagi Penduduk WNI dan WNA yang memiliki Izin Tinggal Tetap dilakukan setelah memenuhi syarat berupa:

1) KK lama

2) Surat Keterangan Kematian atau

3) Surat Keterangan Pindah/Surat Keterangan Pindah Datang bagi penduduk yang pindah dalam wilayah NKRI

f. Penerbitan Kartu Keluarga Hilang atau Rusak bagi penduduk WNI dan WNA yang memiliki Izin Tinggal Tetap dilakukan setelah memenuhi syarat berupa:

1) Surat Keterangan Kehilangan dari kepala desa/lurah

2) KK yang rusak

3) Fotokopi atau menunjukkan dokumen kependudukan dari salah satu anggota keluarga, atau

4) Dokumen keimigrasian bagi orang asing

g. Prosedur dan Tata Cara Penerbitan Kartu Keluarga adalah sebagai berikut:

1) Pemohon meminta Surat Pengantar dari RT/RW. Pemohon menyampaikan Surat Pengantar ke Desa/Kelurahan dengan melampirkan persyaratan yang dibutuhkan sebagaimana dimaksud;

2) Pemohon mengisi data keluarga dan biodata setiap anggota keluarga ( $F 1.01$ ) atau Formulir Perubahan Data/Penambahan Data Anggota Keluarga (F-1.03);

3) Petugas di Desa/Kelurahan menerima dan meneliti kelengkapan berkas persyaratan dan mencatatatnya dalam Buku Harian Peristiwa Penting dan Kependudukan (BHPPK) dan Buku Induk Penduduk (BIP);

4) Pemohon atau petugas Desa/Kelurahan mengisi formulir jenis F-1.01 yang diketahui oleh Kepala Desa/Lurah dan menyampaikan formulir tersebut ke Kecamatan; Petugas di Kecamatan menerima dan meneliti kelengkapan berkas persyaratan dan mencatatanya dalam Buku Harian Peristiwa Penting dan Kependudukan (BHPPK) dan Buku Induk Penduduk (BIP);

5) Petugas pendaftaran Penduduk tingkat Kecamatan menerbitkan KartunKeluarga dalam rangkap 4(empat);

6) Petugas Kecamatan yang telah diberi Surat Perintah (SP) oleh Camat menyampaikan KK kepada Instansi Pelaksana berikut kelengkapan berkas persyaratan serta Surat 
Pengantar yang ditandatangani oleh Camat atau Kepala Seksi Pemerintahan yang memuat daftar nama-nama pemohon KK sesuai dengan format yang tercantum dalam Lampiran Peraturan ini;

7) Petugas pendaftaran penduduk pada Instansi Pelaksana melakukan verifikasi dan validasi data KK, kemudian diparaf oleh Pejabat teknis pada Bidang Pendaftaran Penduduk, selanjutnya ditandatangani oleh Kepala Instansi Pelaksana;

8) KK yang telah ditandatangani oleh Kepala Instansi Pelaksana selanjutnya diambil oleh Petugas Kecamatan untuk diserahkan kepada pemohon;

9) Penyelesaian penerbitan penandatanganan KK adalah paling lambat 14 (empat belas) hari kerja terhitung sejak berkas diterima dan dinyatakan lengkap oleh petugas Kecamatan.

\section{Kualitas Pelayanan Publik dalam Pelayanan Kartu Keluarga}

Kualitas pelayanan pubik yang dikemukakan oleh Zeithmal,Berry dan Parasuram (Fandy Tjiptono,2005:70). Dimensi yang dimaksud meliputi bukti fisik (Tangible), Kehandalan (Reliability), Daya Tanggap (Responsivess), Jaminan (assurance) serta empati (empaty). Peneliti juga meneliti kendala dalam pelayanan publik yang diberikan oleh kantor Kecamatan Purwosari serta upaya meningkatkan kualitas pelayanan di instansi pemerintah tersebut.

Seperti yang telah disebutkan sebelumnya,salah satu sarana pendukung pelayanan dalam mekanisme perubahan atau penggatian Kartu Keluarga (KK ialah ketepatan dalam pelayanan dan kecepatan dalam melayani masalah ketepatan waktu selesainya dalam perubahan atau penggantian Kartu Keluarga tergantung Dukcapil Purwosari, Karena Kantor Kecamatan Purwosari hanya melakukan pengimputan data saja dan memberikan surat pengantar untuk dibawa ke Dukcapil Purwosari.paling tidak biasanya 2 hari sudah selesai . Berdasarkan dari pengamatan peneliti juga melihat karna keterbatasan petugas atau pegawai dan alat yang digunakan untuk pencatatan data masyarakat yang melakukan perbaikan atau penggatian Kartu Kelvarga (KK) masih secara manual sehingga pencatatan terkesan lama.

\section{Bukti Fisik}

Dalam mewujudkan pelayanan yang berkualitas perlu dilakukan perubahan dan perbaikan yang mengarah pada kepuasan masyarakat. Salah satu aspek yang harus diperbaiki dalam meningkatkan kualitas pelayanan yaitu masalah fasilitas pelayanan. peranan sarana pelayanan sangat penting dan salah satu yang sangat berpengaruh terhadap peningkatan kualitas pelayanan publik kareana adanya sarana pelayanan vang memadai sehingga dapat membuat pelayanan pada masyarakat dapat lebih memberikan kenyamanan dan kepuasan selama berada dirungan pelayanan. 


\section{Journal Publicuho}

ISSN2621-1351 (online), ISSN 2685-0729 (print)

Volume 4 Number 1 (February-April), (2021)pp.78-89

Accredited SINTA SK.NOMOR 28/E/KPT/2019

Open Access at:http://ojs.uho.ac.id/index.php/PUBLICUHO/index

DOI: 10.35817/jpu.v4i1.16233

Berdasarkan hasil penelitian yang dilakukan dalam aspek bukti fisik Kator Kecamatan Purwosari Untuk kapasitas jumlah petugas pelayanan 5 orang.Ruangan pelayanan terdapat meja pelayanan, satu unit computer dan kursi tiga set untuk masyarakat yang menunggu pelayanan, terdapat kipas angin untuk masyarakat yang menunggu pelayanan perbaikan maupun pergantian Kartu Keluarga. Bukti fisik, peralatan, personil dan komunikasi .Di Kecamatan Purwosari Kabupaten Pasuruan ini para pegawai atau petugas sudah disiplin tentang etika berpakaian yang rapi begitupulah dengan prasarana yang sudah dimiliki sudah memadai, meskipun untuk komputer masih kurang dikarenakan kurangnya anggran dana untuk pembelian prasarana. Akses wifi yang masih terbilang low dan sering trouble. dalam Keputusan Mentri Pendayagunaan Aparatur Negara No. 63/KEP/M.PAN/7/2003 yaitu tersedianya sarana dan prasarana kerja dan pendukung lainnya yang memadai termasuk penyediaan sarana teknologi telekomunikasi dan informatika dan UU No. 25 Tahun 2009 di jelaskan bahwa penyediaan fasilitas dan sarana prasarana pelayaan yang memadai oleh penyelenggaraan publik.

\section{Kehandalan}

Salah satu indicator dalam memperoleh kualitas pelayanan yang baik ,maka yang perlu untuk diperhatikan yaitu kehandalan.pelaksanaan pelayanan public yang sangat diharapkan oleh masyarakat sebagai konsumen yaitu memberikan pelayanan terutama mereka yang berinteraksi langsung dengan masyarakat.

Dalam kaitanya dengan indicator kehadalan yang diberikan oleh pegawai Kecamatan Purwosari untuk menciptakan pelayanan yang berkualitas adalah malalui interaksi secara langsung dari pemohon perbaikan Kartu Keluarga di Kecamatan Purwosari.

Pada kenyataanya petugas atau aparat Kecamatan Purwosari dalam memberikan pelayanan kepada masyarakat sudah tepat.Berikut ini akan disajikan fenomenanya,hasil wawancara dengan salah satu informan bernama Muhammad Siswanto yang merupakan salah satu seorang warga dari Purwosari yang mengurus Kartu Keluarga guna pindah ke Kecamatan Purwodadi yang mengatakan bahwa:

"Dalam pengurusan Perbaikan Kartu Keluarga di Kecamatan Purwosari dimana petugas yang melayani memberikan pelayanan sesui dengan apa yang saya butuhkan.penaganannya yang handal, cepat tanggap, petugasnya pun ramah sangat memuaskan sekali menurut saya" (hasil wawancara tanggal 06 januari 2021)

Begitu juga dengan halnya yang dikatakan oleh Nuril Khasanah salah satu ibu Rumah tangga dari Desa Sekarmojo yang juga mengurus Kartu Kelurga mengatakan bahwa:

"Kalau masalah kehandalan didalam memberikan pelayanan,petugas di Kecamatan Purwosari sudah memberikan pelayanan yang sesuai.pelayanannya cepat tidak seperti di desa yang berbelit-belit,berbeda dengan di Kecamatan Purwosari selama ini saya dilayani sesuai dengan kebutuhan saya"(hasil wawancara tanggal 06 januari 2021) 
Wawancara diatas dipertegas dengan pengamatan penulis, dimana petugas atau aparat didalam memberikan pelayanan kepada masyarakat yang berurusan di Kecamatan Purwosari memberikan perhatian kepada masyarakat yang dating mengurus Kartu Keluarga ataupun dokumen lainnya.

Dari hasil wawancara diatas dilihat dari indikator kehandalan pegawai di Kecamatan Purwosari dalam perbaikan atau penggantin Kartu Keluarga sudah memuaskan. Ndraha (1999:7) mengemukakan bahwa sebagai unit kerja public,pemeritahan bekerja guna memenuhi dan melindungi kebutuhan, kepentingan dan tuntutan pihak yang diperintah sebagai consumer dan sovereign,akan jasa public dan layanan civil,dalam hubungan pemerintahan.

\section{Daya Tanggap}

Berkaitan dengan kualitas pelayanan pengurusan kartu keluarga dengan tolak ukur daya tanggap ,dalam hal Kecamatan Purwosari terus beruapa meningkatkan mutu pelayanan kepada masyarakat.

Berikut ini wawancara dengan Bapak Eka Wara Brehaspati Selaku Camat di Kecamatan Purwosari bahwa:

"Dalam memberikan pelayanan kepada masyrakat kami terus berusaha dan berupaya untuk meningkatkan kualitas pelayanan, dengan terus membenahi kekurangan-kekurangan selama ini. berkaitan dengan masalah daya tanggap dan kecepatan pelayanan kami kepada masyarakat sudah cukup memuaskan walaupun belum sepenuhnya sesuai dengan harapan masyarakat.Adapun kendala yang masih ada yaitu kurangnya pegawai dibagian pelayanan.( hasil wawancara tanggal 23 desember 2020).

Dari hasil wawancara diatas dapat diketahui bahwa Kecamatan Purwosari sudah terus berusaha dan berupaya dalam memberikan pelayanan yang terbaik kepada masyarakat yang bermohon untuk pengurusan Kartu Kelurga.gambaran bahwa secara keseluruhan unsur yang berada di Kecamatan Purwosari baik itu pimpinan maupun staf berupaya memberikan pelayanan yang mkasimal kepada masyarakat.

Sistem pelayanan adalah suatu rangkaian yang saling kait mengakait secara utuh membentuk kebulatan dalam rangka memberikan pelayanan yang terbaik kepada masyarakat sebagai pengguna jasa dari pelayanan public.Dalam memberikan pelayanan Kartu Kelurga pada Kecamatan Purwosari harus tetap memperhatikan setiap tuntutan konsumen sebagai pengguna jasa dari pelayanan publik.

\section{Jaminan}

Jaminan diperlukan untuk masyarakat merasa puas karena telah mendapatkan pelayanan yang baik dan berkualitas.Jaminan yang dimaksud daat terwujud apabila pegawai dikantor Kecamatan Purwosari dapat menumbuhkan kepercayaan dihati masyarakat atau kosumen 


\section{Journal Publicuho}

ISSN2621-1351 (online), ISSN 2685-0729 (print)

Volume 4 Number 1 (February-April), (2021)pp.78-89

Accredited SINTA SK.NOMOR 28/E/KPT/2019

Open Access at:http://ojs.uho.ac.id/index.php/PUBLICUHO/index

DOI: 10.35817/jpu.v4i1.16233

yang mengggunakan jasa pelayanan. Petugas dapat menjaga komunikasi atau interaksi dengan baik antar pegawai ataupun dengan masyarakat.di samping itu Kecamatan Purwosari hendaknya memberikan jaminan kepada masyarakat pemohon pelayanan dan jaminan itu berupa kemudahan akses pelayanan karena semua persyaratan apa yang harus dipenuhi sudah dijelaskan oleh petugas dan itu merupakan upaya untuk memberikan jaminan kemudahan pelayanan kepada masyarakat.

Petugas pelayanan di Kecamatan Purwosari telah berusaha semaksimal mungkin untuk melaksanakan tugas dengan baik,supaya ketika ada keluhan dari masyarakat agar segera diatasi atau ditindak lanjuti.peyelenggaraan pelayanan di bagian pelayanan di Kecamatan Purwosari dilakukan dengan mengusahakan agar dapat terselenggra secara efektif dan efisien. Oleh karena itu masyarakat yang menerima layanan maupun petugas yang memberikan pelayanan harus memahami prosedur pelayanan yang sudah berlaku.

\section{Empati}

Empati adalah perhatian yang tulus dan bersifat individual ataupun pribadi yang diberikan kepada masyarakat dengan upaya memenuhi kegiatan masyarakat. dimensi empati ini memegang peran yang penting dalam mengukur kualitas pelayanan,sebab sikat yang baik dari petugas pelayanan akan menumbuhkan rasa nyaman kepada dinas atau instansi terkait.Kepedulian pegawai untuk selalu mengutamakan kebutuhan masyarakat akan mendukung terciptanya kualitas pelayanan publik. Sikap empati atau kepedulian yag di tunjukkan oleh masyrakat yaitu dengan menjelaskan secara jelas dan lugas supaya pelayanan dapat diterima dengan baik oleh masyarakat dan juga menerima kritik dan saran dengan sepenuh hati untuk evaluasi terhadap pelayanan yang lebih baik.

Hasil observasi dan wawancara dari penelitian penulis juga menunjukkan bahwa pegawai atau petugas Kecamatan Purwosari Kabupaten Pasuruan dalam menjalankan pelayanan public kepada masyarakat sudah maksimal dalam hal keramahan .Misalnya pada saat melayani pemohon perbaikan Kartu Keluarga petugas atau pegawai dengan sigap melayani pemohon dengan ramah dan sopan. Begitu pula dengan petugas bagian pelayanan yang mengarahkan masyarakat yang masih belum paham akan prosedur permohonan Kartu Keluarga di Kecamatan Purwosari. 


\section{KESIMPULAN}

Berdasarkan hasil penelitian dan uraian pembahasan tentang Kualitas Pelayanan Publik Dalam Mekanisme Pelayanan Kartu Keluarga (KK) Di Kecamatan Purwosari Kabupaten Psurvan, diperoleh kesimpulan sebagai berikut :

1. Aspek tangible, berdasarkan hasil penelitian yang dilakukan terkait dengan bukti fisik ,fasilitas pendukung pelayanan di Kecamatan Purwosari sudah cukup memadai dan memuaskan masyarakat.

2. Dari aspek reability atau kehandalan di Kecamatan Purwosari telah melakukan pelayanan yang sangat baik.Hal ini ditandai dengan SOP (Stadart operating procedure)

3. Berdasarkan aspek responsiveness diketaui bahwa pegawai atau petugas di kantor Kecamatan Purwosari melayani masyarakat dengan baik .pegawai merespon hal-hal yang ditanyakan masyarakat dan memberikan pengarahan terkait dengan pertanyaan tersebut.pegawai atau petugas melayani masyarakat dengan ramah dan sopan.

4. Dari aspek assurance dapat ditarik kesimpulan bahwa kantor Kecamatan Purwosari telah memberika jaminan kemudahan pelayanan kepada masyarakat yang mengajukan permohonan pelayanan di Kecamatan Purwosari.

5. Dilihat dari aspek empaty, kantor Kecamatan Purwosari telah memberikan pelayanan yang baik dan memuaskan hal ini tercapai karena pegawai atau petugas yang melayani masyarakat memiliki sikap yang ramah dalam menghadai permintaan kritik dan saran yang diberikan oleh masyarakat.

6. Kendala yang dihadapi untuk mewujudkan pelayanan yang lebih baik di Kecamatan Purwosari Kabupaten Pasuruan ialah masalah kurangnya petugas atau pegawai di bagian pelayanan dan terbatasnya alat untuk pencatatan data masyarakat . 


\section{Journal Publicuho}

ISSN2621-1351 (online), ISSN 2685-0729 (print)

Volume 4 Number 1 (February-April), (2021)pp.78-89

Accredited SINTA SK.NOMOR 28/E/KPT/2019

Open Access at:http://ojs.uho.ac.id/index.php/PUBLICUHO/index DOI: 10.35817/jpu.v4i1.16233

\section{DAFTAR PUSTAKA}

IAN \& BPKP 2000. Pelayanan public: CV Citra Malang.

Keputusan Menteri Pendayagunaan Aparatur Negara Nomor 63/KEP/M.PAN/7/2003. tentang Pedoman Umum Penyelenggaraan Pelayanan Publik

Lijian Poltak, 2005. Reformasi Pelayanan Publik, Bumi Aksara.Jakarta

Maulid, Y., Deli, A., \& Abdul.W. Kualitas Pelayanan Terpadu Dalam Mekanisme Perbaikan Kartu Kelurga (KK) Di Kecamatan Bati-Bati Kabupaten Tanah Laut (Uniska)

Moleong, Lexy J.,2000, Metodologi Penelitian Kualitatif, Cet. Kedua, Bandung: PT.Remadja Rosdakarya

Nawawi, Hadari., 2007, Metode Penelitian Bidang Sosial, Cetakan Kedua Belas, Yogyakarta : Gadjah Mada University Press

Nur, J., Bake, J., \& Yusuf,M. IMPLEMENTASI KEBIJAKAN PELAYANAN KARTU TANDA PENDUDUK DAN KARTU KELUARGA (Studi Pada Dinas Kependudukan Dan Pencatatan Sipil Kabupaten Konawe Kepulauan). Publica: Jurnal Administrasi Pembangunan dan Kebijakan Publik, 11 , (1) 112-123.

Peraturan Bupati Pasuruan Nomor 5 Tahun 2017

Sugiyono.2016.Metode Penelitian Kulitatif, Kuantitatif, dan R\&D. Bandung: Alfabeta

Tasrif. T. (2016) Kualitas pelayanan pengurusan kartu keluarga dinas kependudukan dan pencatatan sipil kota palu . Katalogis, 4 (9).

Undang-undang nomor 25 tahun 2009, tentang Pelayanan Publik

Undang-undang Nomor 23 tahun 2006, tentang Administrasi Publik

Undang -undang Nomor 43 Tahun 1999 ,tentang Pokok-Pokok Kepegawean 